\title{
COUNTRY RISK PERCEPTIONS AND FOREIGN DIRECT INVESTMENT IN EMERGING MARKET ECONOMIES: A PANEL DATA ANALYSIS
}

\author{
Debabrata Mukhopadhyay ${ }^{1}$ and Dipankar Das ${ }^{2}$ \\ ${ }^{1}$ West Bengal State University, India \\ E-mail: debu1641975@yahoo.co.in \\ ${ }^{2}$ West Bengal State University, India \\ E-mail: ddas233@gmail.com
}

\begin{abstract}
This study aimed at examining the impact of major political risks, financial risks and economic factors on FDI inflows in emerging economies along with basic economic fundamentals such as institutional variables namely, per capita GDP, per capita electric consumption, trade openness and real rate of interest. This study followed a static panel data approach in studying the impact of these crucial variables on FDI inflows in fifteen major emerging economies for the period 2000 to 2014. Risk perceptions i.e., political risks and other risk perception data were collected from the International Country Risk Guide (ICRG) provided by the Political Risk Services (PRS) Group. Our results demonstrate that risk perception components such as government stability, quality bureaucracy etc., are statistically significant with expected signs in explaining variations in FDI inflows in the major emerging countries.
\end{abstract}

Keywords: FDI inflows, emerging economies, risk perception, political risk, macroeconomic fundamentals, static panel model

ARTICLE INFO

Article History:

Received: 4 March 2020

Accepted: 27 June 2020

Published: 31 August 2020 


\section{INTRODUCTION}

Since the early 1990's foreign direct investment (FDI) inflows have been rapidly increasing in emerging market economies (EME) and have become the single largest component of net capital inflows for these countries (IMF Report, 2003). FDI has often been considered as the source of new technology and hence, higher productivity in particular, in emerging market economies (EME). FDI also encourages better governance, efficient allocation of resources and facilitates access to international financial markets (Alfaro, 2017; Ahmed \& Zlate, 2014). The main focus of the literature on FDI inflows in developing countries has been on growth episodes. However, the growth-enhancing benefits of FDI are conditional on local conditions and policies (Alfaro, 2017), institutional quality (Jude \& Levieuge, 2017) and human capital (Jyun-Yi \& Chih-Chiang, 2008).

Although motivation to invest in EME differ across countries and economic sectors, the role of risk perceptions about a stable political environment as well as conditions that support physical and personal security cannot be ruled out. Governance concerns are getting greater attention such as issues relating to the legal framework and the enforceability of contracts. FDI is indeed the main component of international capital flows (Eichengreen, Gupta, \& Masetti, 2018).

In a seminal work, Helpman, Melitz, and Yeaple (2004) observed that high sunk cost of FDI lead to discourage multinational companies to invest in developing economies, an important component of which is related to cost of collecting information so as to overcome the MNEs' lack of knowledge and familiarity with the country. These uncertainties about the ground realities of these countries are associated with poor institutional environments of many emerging countries which have adverse effects on political risks.

Several studies have revealed that country risk is composed of political, economic and financial risks which have a significant effect on FDI inflows (Blonigen, 2005). Wei (2000) has also found that corruption significantly hampers FDI inflows. Kolstad and Tondel (2002) found that FDI flows are affected by ethnic tensions, internal conflicts, and democracy, but not by government stability, bureaucracy, external conflicts, law and order, and 
the military being involved in politics. Busse and Hefeker (2007) found that government stability, internal and external conflicts, corruption, ethnic tensions, law and order, democratic accountability of government, and quality of bureaucracy are highly significant determinants of FDI flows in developing countries. Ali, Fiess, and MacDonald (2010) observed that institutions are robust predictors of FDI and that property rights security is the most important aspect of these institutions in determining FDI inflows. Erkekoglu and Kilicarslan (2016) demonstrated that the impact of political risk on foreign direct investment has demonstrated that an increase in political stability and absence of violence and management effectiveness has reduced foreign direct investment.

Furthermore, some previous attempts have studied the role of risk perception of FDI in developing and emerging economies. However, very few studies have used country risk as an impact variable in the context of a single country or they have studied the impact of a few components of country risk on FDI inflows in one or more countries. Therefore, we bridge this gap empirically in the literature by emerging countries to more accurately measure the importance of risk perception in attracting FDI inflows. Against this backdrop, this study aimed to investigate empirically in a systematic manner the relationship between FDI inflows and country risk in emerging countries.

Thus, this study intended to investigate the impact of risk perceptions in terms of political, financial and economic matters on FDI inflows in emerging market economies. Considering major fifteen emerging economies over the period 2000 to 2014, this study explored the role of risk perceptions on FDI inflows apart from macroeconomic fundamentals as control variables following a static panel data approach. As already stated, the present study considered those emerging countries, which has at least $1 \%$ share in FDI inflows of the total world FDI inflows on an average for the period considered i.e., 2000 to 2014. Risk perceptions consisted of political, financial and economic risk the data for which were collected from the International Country Risk Guide (ICRG).

FDI being the engine of growth for emerging countries is crucially determined by risk perceptions apart from strong macroeconomic fundamentals. The measurement of risk perception is the subjective 
decision of the people and it makes about the nature and intensity of a risk (Mukhopadhyay \& Das, 2019).

There exists a vast and comprehensive literature on the determinants of FDI inflows in the emerging market economies. Studies such as Calvo, Leiderman, and Reinhart (1993) have investigated the determinants of FDI within country-specific (pull) and external (push) factors context. The study carried out by Eichengreen et al. (2018) demonstrated that FDI flows are driven mainly by pull factors, portfolio flows seem to be driven mainly by push factors whilst other investment flows are driven by both push and pull factors. The literature also suggests that some structural domestic conditions (SDC) including trade openness, international financial integration, financial openness, exchange rate regimes and investment environment are important in driving FDI inflows. However, the literature on the role of risk perceptions as FDI determinants consisting of structural domestic conditions is very new.

The risk perceptions methodology that we follow here was derived from the International Country Risk Guide (ICRG) as measured by the Political Risk Services (PRS) Group. Country risk constitutes three major components namely, political, financial and economic. The political risk index depends on twelve sub-components such as government stability, ethnic tensions, religious tensions, socioeconomic conditions, investment profile, internal conflict, external conflict, corruption, military in politics, law and order, democratic accountability, and bureaucracy quality, etc. The financial risk component includes eight subcomponents such as the foreign debt as a percentage of GDP (Gross Domestic Product), foreign debt service as a percentage of the exports of goods and services, current account as a percentage of the exports of goods and services, net international liquidity in terms of months of import cover, exchange rate stability, the inflation rate, the budget balance as a percentage of GDP and current account as a percentage of GDP in the countries. The economic risk is based on five subcomponents such as GDP per capita, real GDP growth rate, annual inflation rate, budget balance as a percentage of GDP and current account as a percentage of GDP. 


\section{Some Relevant Issues in Emerging Countries}

Throughout the last two decades, FDI inflows in developing countries have gradually increased. Therefore, FDI is crucial in the case of developing countries (Fig. 1). Among the emerging countries, most of them are from the Asian continent and few countries were selected from South America, and the remaining taken from the North American continent. The country Russian Federations belongs to Eurasia and one country is from the African continent. Moreover, these emerging countries are now an attractive destination to the MNCs for FDI inflows. According to the International Monetary Fund (IMF), the source of growth of the emerging market economy in the complex global system are increasingly emerging markets.

\section{FDI inflows in developing countries}

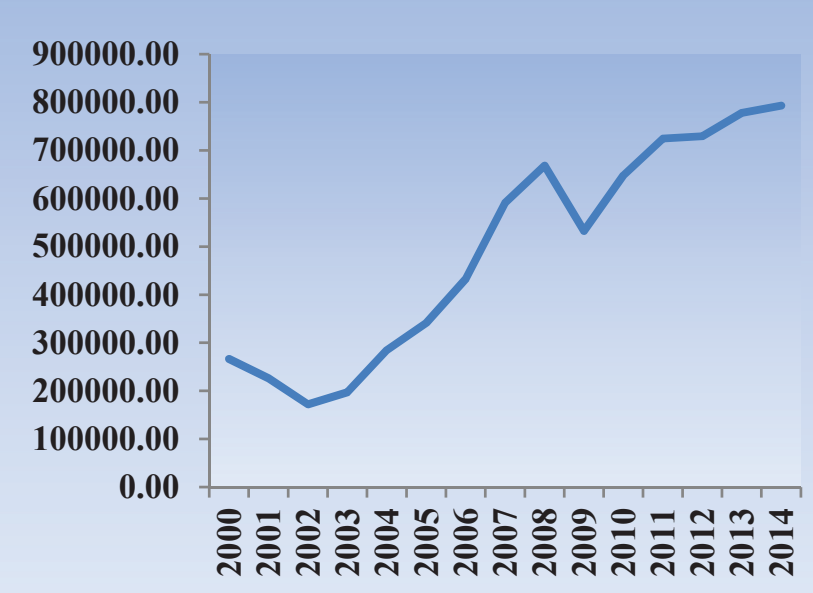

Figure 1: Trend of FDI Inflows to The Developing

Countries During 2000 To 2014

Source: World Bank, during the year $2000-2014$

We present the summary statistics of FDI inflows for the selected emerging countries in Table 1 below. The results show that China has the highest average FDI inflows during this period followed by Hongkong. Countries also differ in terms of standard deviations. 
Table 1: Summary of Statistics about FDI Inflows in Emerging Countries

\begin{tabular}{lcc}
\hline \multicolumn{1}{c}{ Countries } & Average FDI Inflows $^{1}$ & S. D of FDI Inflows \\
\hline Brazil & 39189.67 & 27916 \\
China & 83581.00 & 30618.77 \\
South Africa & 4288.25 & 3184.945 \\
Colombia & 7767.50 & 5077.881 \\
India & 19779.03 & 14411.46 \\
Korea, republic & 9798.96 & 2480.779 \\
Singapore & 31822.30 & 19536.29 \\
Mexico & 25604.51 & 7383.713 \\
Peru & 4947.84 & 3563.092 \\
Russia federation & 28170.71 & 22333.1 \\
Malaysia & 6042.82 & 3771.057 \\
Vietnam & 4882.14 & 3440.82 \\
Chile & 11020.08 & 6637.41 \\
Indonesia & 7089.72 & 8144.26 \\
Hong Kong & 50064.44 & 25464.08 \\
\hline
\end{tabular}

Source: World Bank, during the year $2000-2014$.

\section{LITERATURE REVIEW}

The literature concerning country risk perceptions and its impact on foreign investment inflows in emerging market economies is vast and comprehensive although the conclusions differ widely among these works.

There are few studies, which explain that foreign direct investment, declines as the political risk perception goes up (Gastanaga, Nugent, \& Pashamova, 1998; Wei, 2000; Grosse, \& Trevino 2005; Demirhan \& Masca, 2008; Erramilli \& Rao, 1993). However, there are some studies, which have found that political risk has no effect on FDI inflows (Wheeler \& Moody, 1992; Noorbakhsh, 2001) in emerging countries.

Tallman (1988) conducted a study considering the effect of political and economic conditions of the home country on outward FDI in the case of OECD countries for the period 1974 to 1980 and found that political and economic conditions of the home country are important for the process of foreign direct investment decision. Wheeler and Mody (1992) analyzed

1 Average FDI inflows in emerging countries during the year 2000 to 2014 
company-level data from the USA and found that corruption in the host country does not have any significant effect on foreign direct investment inflows.

Collier and Pattillo (2000) found that political risk has a significant impact on private investment and that firms have limited means of reducing these risks. Since the legal status of expropriation or guidelines for compensation for expropriation has not been entirely defined in international law, host governments have further incentives to not abide by the property rights of MNCs (Thomas \& Worrall, 1994).

Noorbakhsh, Paloni, and Youssef (2001) examined that the relation between the human capital level of the host country and the geographical distribution of foreign direct investment for the years 1980 to 1994 covering 36 developing countries from Africa, Asia and Latin America, and observed that the variables of democracy and political risk had no significant effect on foreign direct investment inflows.

Busse and Hefeker (2007) examined that the relationship between political risk, corporations and foreign direct investment flows with 83 developing countries between 1984 and 2003, and found the variables of political risk and institutions except for government stability, law and order, and quality of the bureaucracy. Selected variables like investment profile, internal and external conflicts, ethnic conflicts, and democratic accountability are considered as statistically significant determinants of FDI flows.

Kolstad and Villanger (2008) applied panel data analysis to examine the determinants of FDI flows in the services sector using the data on FDI inflows from 57 countries, including developed, transition and developing countries, for the period 1989 to 2000, and concluded that institutional quality, democracy, and market size are significant determinants in case FDI inflows etc.

Veld and Veld-Merkoulova (2008) studied that the risk perception of individual investors by using an experimental questionnaire study on 2,226 members in a consumer panel, and found that most investors implicitly use more than one risk measures. They also found that investors systematically 
perceived risk according to the same risk measures was most popular to their semi-variance return on investment and stock investors chose the semi variance of the risk measure.

Krifa-Schneider and Matei (2010) used the fixed-effect model and dynamic panel data model to reveal that the relationship between political risk, business climate and foreign direct investment empirically and found that significant results within the 33 developing countries and transition countries.

Hayakawa, Kimura, and Lee (2013) observed the effect of political and financial risk on FDI inflows in 93 countries and 63 countries of them were developing countries. Using dynamic GMM and the fixed effects model in their study they are of the view that a high level of political risk decreases FDI inflows. Besides that, financial risk components do not effect FDI inflows.

Palacios and Griffin (2011) demonstrate that the regression results have shown the correlation between FDI and 13 risk variables including financial, political and macroeconomic risks for six Latin America Countries (Argentina, Brazil, Chile, Colombia, Mexico and Venezuela). The regression results explain a negative correlation between countries' risk levels and FDI inflows.

Asiri and Hubail (2014) used the Eurom and Economic Intelligence Unit indices to measure political risk for their study examining political and economic factors that influence the determination of country risk ratings. Asiri and Hubail (2014) found that country risk (political risk as a component of country risk) analysis is crucial for the profitability of overseas investments because it helps investors make rational decisions to limit foreign risks.

Valentine (2015) has observed that the relationship between left-wing government and political risk and FDI inflows by using the data on OECD counties. The results are not matched with the main hypothesis i.e., there is a significantly positive relationship between right-left party orientation and FDI Inflows. 


\section{DATA AND METHODOLOGY}

This section deals with data and methodology approach to be followed in the study. As already discussed in the previous section, this study addressed the issue of the role of the different risk perceptions on FDI inflows in fifteen emerging economies ${ }^{2}$ from 2000 to 2014 which were obtained from the World Investment Report of the UNCTAD (United Nations Conference on Trade and Development; www.unctad.org) following a static panel approach. The explanatory variables in this study were risk perceptions consisting of political, economic and financial risk drawn from the ICRG (International Country Risk Guide) provided by the PRS Group (www.prsgroup.com)

The other explanatory variable, such as the OECD national accounts data files and institutional factor as per capita electric consumption $\left(Z_{1}\right)$ figures were taken from the OECD and IEA report of 2014. Trade openness $\left(Z_{2}\right)$ of the emerging economies was available in the World Bank national accounts data. Real Rate of Interest $\left(Z_{3}\right)$, figures were taken from IMF and International Financial Statistics. An explanatory variable considered was infrastructure quality, which is per capita electric consumption in the countries. The research expected that this variable was positively related to FDI inflows. Another explanatory variable was trade openness, defined as countries exports plus imports divided by GDP. Countries that are more open to trade are expected to be more open to foreign investments. The last explanatory variable was the real rate of interest which is also negatively related to FDI inflows.

\section{Brief Descriptions of Risk Perception Data}

The ICRG rating is a combination of 22 variables in three categories of the risk index such as political risk, financial risk, and economic risk index and each index have different subcategories. The Political Risk index is based on 100 points where scores ranging from $0-49.9$ per cent implies very high risk, 50-59.9 per cent explains high risk, 60-69.9 per cent moderate risk, 70-79.9 per cent low risk and finally, $80-100$ per cent indicated very low risk. Financial Risk is based on 50 points and Economic Risk on 50 points. The ICRG model for forecasting the editors of International Reports, a widely

2 These economies are Brazil, Chile, China, Colombia, Hong Kong SAR, India, Indonesia, Korea Rep, Malaysia, Mexico, Peru, Russian Federation, Singapore, South Africa, and Vietnam. 
respected weekly newsletter on international finance and economics, created financial, economic, and political risk in 1980. The ICRG staff collect data about the political and financial and economic information and it converting into risk points for each individual risk component based on a consistent pattern of evaluation. The political risk assessments are made based on subjective analysis of the available information, while the financial and economic risk assessments are made solely based on objective data. The 12 political risk components and associated scores are stated in Table 2 below

Table 2: Political Risk Component

\begin{tabular}{lc}
\hline \multicolumn{1}{c}{ Political Risk Component } & Points \\
\hline Government Stability $\left(\mathrm{X}_{1}\right)$ & 12 \\
Socioeconomic Conditions $\left(\mathrm{X}_{2}\right)$ & 12 \\
Investment Profile $\left(\mathrm{X}_{3}\right)$ & 12 \\
Internal Conflict $\left(\mathrm{X}_{4}\right)$ & 12 \\
External Conflict $\left(\mathrm{X}_{5}\right)$ & 12 \\
Corruption $\left(\mathrm{X}_{6}\right)$ & 6 \\
Military in Politics $\left(\mathrm{X}_{7}\right)$ & 6 \\
Religious Tensions $\left(\mathrm{X}_{8}\right)$ & 6 \\
Law and Order $\left(\mathrm{X}_{9}\right)$ & 6 \\
Ethnic Tensions $\left(\mathrm{X}_{10}\right)$ & 6 \\
Democratic Accountability $\left(\mathrm{X}_{11}\right)$ & 6 \\
Bureaucracy Quality $\left(\mathrm{X}_{12}\right)$ & 4 \\
\hline Total & $\mathbf{1 0 0}$ \\
\hline
\end{tabular}

Government stability is a component of the political risk index, which is the sum of three subcomponents (government unity, legislative strength, popular support), each with a maximum score of four points and a minimum score of 0 points. The score of 4 points indicating a very low risk and the score of 0 points indicating a very high risk. Thus, government stability has maximum points of 12. Similarly, total scores of Socioeconomic Conditions, Investment Profile, Internal Conflict, and External Conflict components is twelve scores each.

On the other hand, corruption, military in politics, religious tension, law and order, ethnic tension and democratic accountability etc. components have six scores. Lastly, bureaucratic quality has a total score of four. Investment profile, i.e., factors related to risk of investment that are not covered by other (financial and economic) risk components, such as contract 
viability (expropriation), profits repatriation or payment delays. Internal conflict is an assessment of political peacefulness or violence within the country and its real or potential negative impact on governance and as a result it distorted the FDI in the country. External conflicts mainly depend on violations among the countries, aggressive mentalities, conflict, etc. among the countries. Corruption is a measurement of corruption within the political system and it reduces foreign investment for several reasons and it hampers the economic and financial environment; it declines the efficiency of the government. Military in politics represents the influence of the military in politics, which could signal that the government is unable to function effectively and that the country might have an unfavorable environment for business. Religious tensions stem from the domination of society and governance by a single religious group seeking, for instance, to replace civil by religious law or to exclude other religions from the political and social process. Law and Order measures strengthen the impartiality of the legal system. Ethnic tension is an assessment of the dimension of pressure within a country attributable to racial, nationality, or language divisions. Its lower ratings are shown in the countries where racial tensions and nationality tension both are high because opponent groups are intolerant and unwilling to compromise everywhere. Its higher ratings indicate countries where tensions are lower. In general, in case of democratic accountability, the highest number of risk points (lowest risk) is assigned to alternating democracies, while the lowest number of risk points (highest risk) is assigned to autarchies. In case of quality of bureaucracy, institutional strength and quality of the bureaucracy is another threat to investors because when government changes in the countries previous policies may also be changed.

On the other hand, financial risk components consist of five sub components. In general terms if the points get less than 50 percent of the total, that component is to be considered as very high risk. If the points are in the 50-60 percent range it indicates high risk and in the $60-70$ percent range shown in moderate risk, in the $70-80$ percent range represents low risk and, in the 80-100 percent, range explains very low risk. The financial risk components are elaborated in Table 3 below. 
Table 3: List of Financial Risk Component

\begin{tabular}{lc}
\multicolumn{1}{c}{ Financial Risk Component } & Points \\
\hline Foreign Debt as a Percentage of GDP $\left(\mathrm{X}_{13}\right)$ & 10 \\
Exchange Rate Stability $\left(\mathrm{X}_{14}\right)$ & 10 \\
Foreign Debt Service as a Percentage of Exports of Goods & 10 \\
and Services $\left(\mathrm{X}_{15}\right)$ & 15 \\
Current Account as a Percentage of Exports of Goods and & \\
Services $\left(\mathrm{X}_{16}\right)$ & 5 \\
Net International Liquidity as Months of Import Cover $\left(\mathrm{X}_{17}\right)$ & $\mathbf{5 0}$ \\
\hline Total
\end{tabular}

Economic risk index provides the countries current economic strengths and weakness. In general terms where its economic strengths outweigh its weaknesses, means it will present a low economic risk. On the other hand, when economic weaknesses outweighing its strengths will present a high economic risk in the countries. Economic risk components are given in Table 4.

Table 4: List of Economic Risk Component

\begin{tabular}{lc}
\hline \multicolumn{1}{c}{ Economic Risk Component } & Points \\
\hline Annual inflation rate $\left(\mathrm{X}_{18}\right)$ & 10 \\
GDP per capita $\left(\mathrm{X}_{19}\right)$ & 5 \\
Real GDP growth rate $\left(\mathrm{X}_{20}\right)$ & 10 \\
Budget balance as a percentage of GDP $\left(\mathrm{X}_{21}\right)$ & 10 \\
Current account as a percentage of GDP $\left(\mathrm{X}_{22}\right)$ & 15 \\
\hline Total & $\mathbf{5 0}$ \\
\hline
\end{tabular}

The following figures (Figure 1 and Figure 2) present the position of each selected country with respect to FDI inflows in two different years, namely 2000 and 2014, respectively. As far as the country wide position in the year 2000 is concerned, Hongkong had the highest FDI inflows, in 2014, China attracted the highest level of FDI inflows followed by Hong Kong. 


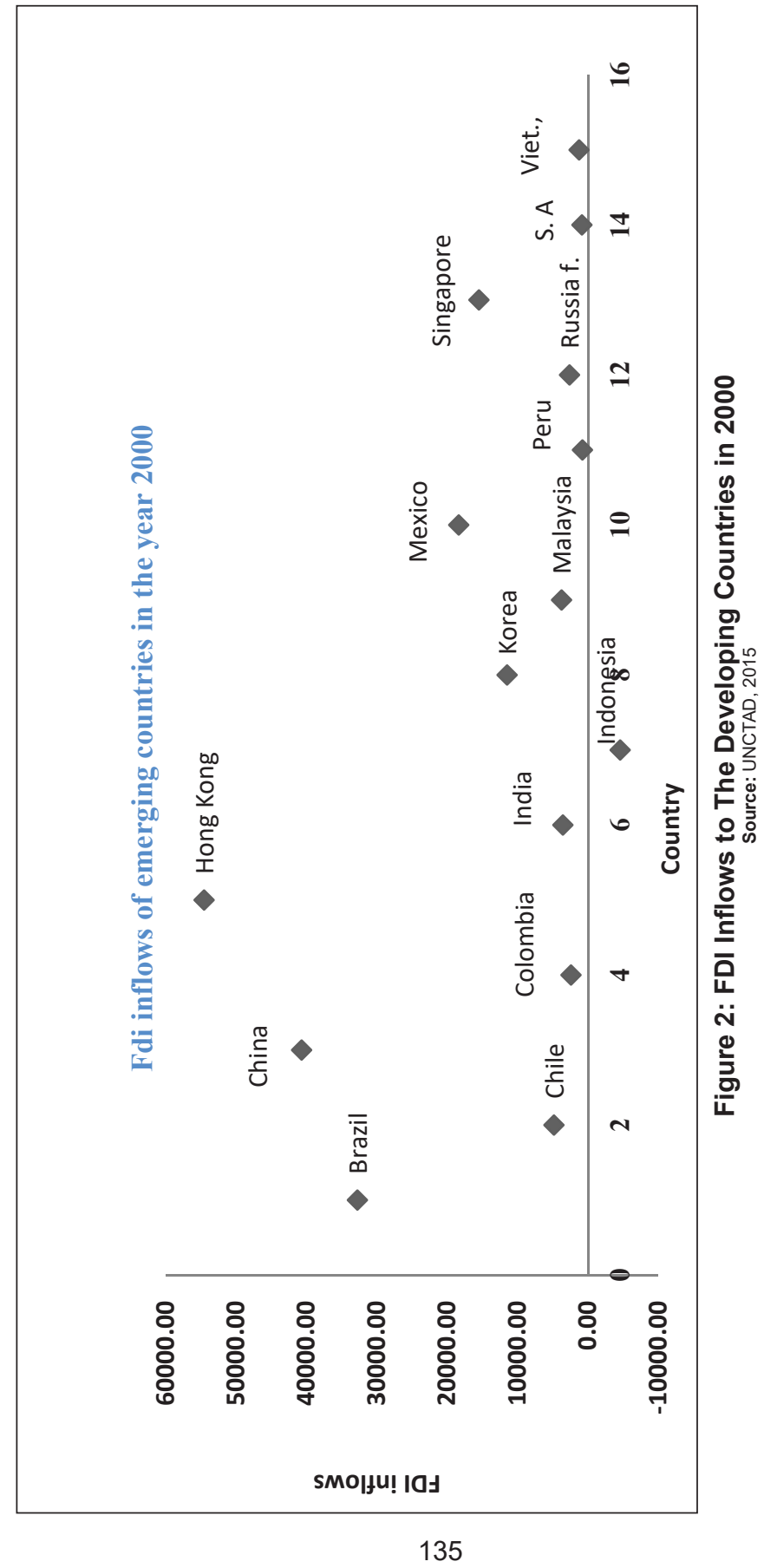


Asia-Pacific Management Accounting Journal, Volume 15 Issue 2

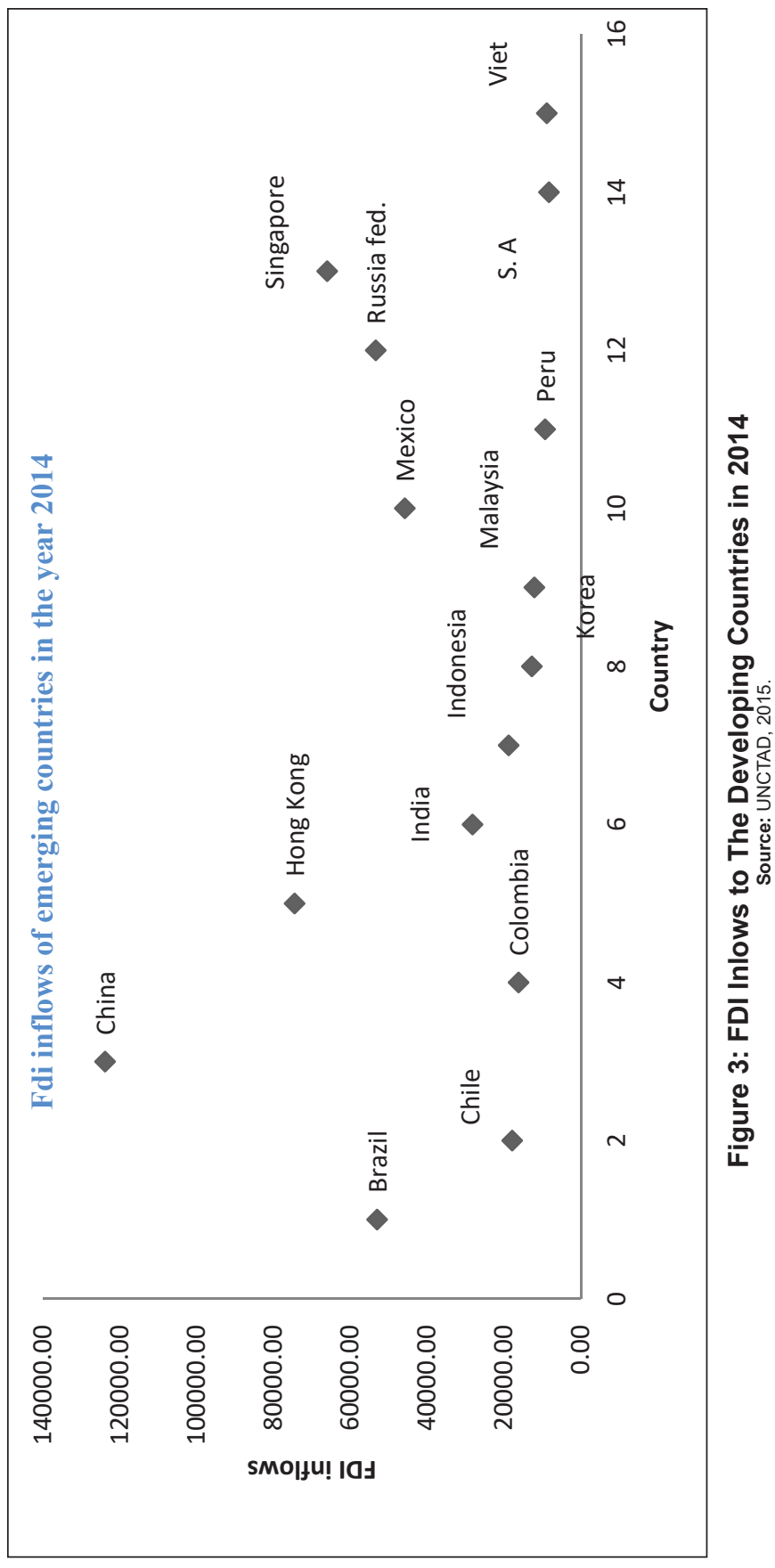




\section{Methodology}

This study was carried out by following the econometric methodology of static panel data analysis under the fixed-effect (FE) model.

The static panel data regression model used in our study is of the following form:

$$
Y_{i t}=\alpha_{i}+\sum_{k=1}^{3} \beta_{1 k} Z_{k, t}+\sum_{l=1}^{2} \beta_{2 l} X_{l, t}+u_{t}
$$

In the above panel regressions model (1), $Y_{i t}$ represents the FDI inflows in the $i$ th country in the $t$ th year, the explanatory variable $X_{l t}$ represents in the $i$ th country and $t$ th year $l$ risk component. $Z_{k}$ 's represents the macroeconomic control variables. The disturbance or error term $u_{i t}$ takes into account both the unobservable unit of observation specific effects and the remainder of the disturbance. Where, $\alpha_{i}$ denotes intercept term and $\beta$ denotes a vector of coefficients.

\section{EMPIRICAL RESULTS}

The regressions results are reported in Table 5. As stated earlier, this study investigated the relationship between FDI inflows and country risk components in fifteen emerging counties during the year 2000 to 2014 along with control variables. Apart from country risk component control variables such as trade openness, institutional variables such as GDP per capita, per capita electric consumption and real interest rate in the host countries were also considered in the analysis.

\section{Political Risk and FDI Inflows}

There are many sub-components of country risks, which are statistically significant to cause FDI inflows in emerging countries. The value of $\mathrm{R}^{2}$ is about 88 per cent and the $\mathrm{F}$ test is statistically significant. This means that 88 per cent of the variation in FDI level is explained by the explanatory variables. There are seven-sub components of political risk index are statistically significant such as government stability, socioeconomic 
conditions, corruption, military in politics, religious tension, law and order, ethnic tension. Strong government stability in emerging countries may be attractive to foreign investors. They are strong determinants in FDI inflows in emerging countries. The results show that government stability, socioeconomic conditions, military in politics, and religious tension have a positive impact on FDI inflows in developing countries, as the coefficients are positive. The subcomponent of the political risk index i.e. government stability is positively correlated with FDI inflows in emerging market economies and statistically significant at the 1 per cent level. Government stability shows that foreign investors are also highly sensitive to changes in political stability and the framework in which governments operate. Fundamental democratic rights, like civil liberties and political rights, do matter to multinationals operating in developing countries for investment. Another factor of the political risk index, socioeconomic conditions are positively related to FDI inflows in emerging countries and statistically significant at the 1 per cent level. In the case of the socioeconomic conditions, which has been a positive sign and it means that an improvement of the socio-economic condition is positively related with FDI inflows in emerging countries. The socioeconomic condition consists of the unemployment rate, consumer confidence, and the poverty rate.

Estimated results show that the risk component corruption is negatively related to FDI inflows in emerging countries at the 10 per cent level of significance. Low corrupted countries appreciated high FDI inflows in emerging countries.

Military in politics is also positively related to FDI inflows in emerging countries and statistically significant at the 10 per cent level. Military gets involved in government because of an actual or created internal or external threat. Such a situation would imply the distortion of government policies to meet this threat by increasing the defence budget at the expense of other budget allocations.

Religious tensions have a positive impact on FDI inflows in developing countries and it is statistically significant at the 5 per cent level of significance. This means that when religious tensions in any country decreases, the bad foreign investment environment intensively decreases. 
In the case of the law and order component, the estimated value is statistically significant at the 1 per cent level and negatively related to FDI inflows. The sub-component Law is an assessment of the strength, weakness, and impartiality of the legal system. On the other, the sub-component Order is an assessment of observation of the people of the law.

For the Ethnic tensions order component the estimated value is statistically significant at the 5 per cent level and negatively related with FDI inflows. Low ethnic tensions allowed for high FDI inflows in emerging countries.

\section{Financial Risk and FDI Inflows}

The study also examined the effects of the different components of financial risk on FDI inflows in emerging countries. The static panel result is present in Table 5. Here among all factors, there are three components which are statistically significant, which are foreign debt service as a percentage of exports of goods and services, current account as a percentage of exports of goods and services and net international liquidity as months of import cover. The factor of foreign debt service as a percentage of exports of goods and services is negatively related to FDI inflows and it is significant at the 1 per cent level of significance. Current account as a percentage of exports of goods and services has a positive impact on FDI inflows in developing countries and it is significant at the 5 per cent level of significance. Net international liquidity as months of import covered is also positively related to FDI inflows in emerging countries and statistically significant at the 1 per cent level.

\section{Economic Risk and FDI Inflows}

In this section, the study discusses the empirical relation between FDI inflows and economic risk components. The statistical computation is also reported in Table 5. Only three subcomponents of economic risks are statistically significance such as annual inflation rate, GDP per capita, budget balance as a percentage of GDP. The annual inflation rate is negatively related to FDI inflows and it is significant at the 5 per cent level of significance. High inflation rate creates economic distortion and results in risks for investments. In the case of GDP, the estimated value 
is statistically significant at the 1 per cent level and positively related to FDI inflows. This is a good economic atmosphere for a foreign investor in case of investments. When GDP per capita increases then FDI inflows also increases. The economic risk component, budget balance as a percentage of GDP is also statistically significant at the 5 per cent level and positively related to FDI inflows.

Table 5: Static Panel Regression Results for 15 Emerging Countries for The Period 2000-2014

\begin{tabular}{|c|c|c|c|c|}
\hline Variables & Coefficient & Std. Error & t-Statistic & P-value \\
\hline Constant & -10180.69 & 21564.34 & 0.471 & 0.00 \\
\hline Government Stability $\left(\mathrm{X}_{1}\right)$ & 2093.58 & 750.02 & 2.79 & $0.00^{* * *}$ \\
\hline Socioeconomic Conditions $\left(\mathrm{X}_{2}\right)$ & 4642.78 & 1175.70 & 3.94 & $0.00^{* * *}$ \\
\hline Corruption $\left(\mathrm{X}_{6}\right)$ & -2849.90 & 1703.85 & -1.67 & $0.09^{*}$ \\
\hline Military in Politics $\left(\mathrm{X}_{7}\right)$ & 4659.55 & 2619.67 & 1.77 & $0.07^{*}$ \\
\hline Religious Tensions $\left(\mathrm{X}_{8}\right)$ & 4830.51 & 2300.53 & 2.09 & $0.03^{\star *}$ \\
\hline Law and Order $\left(\mathrm{X}_{9}\right)$ & -10868.15 & 2863.59 & -3.79 & $0.00^{* * *}$ \\
\hline Ethnic Tensions $\left(\mathrm{X}_{10}\right)$ & -4762.71 & 2429.51 & -2.28 & $0.05^{\star *}$ \\
\hline $\begin{array}{l}\text { Foreign Debt Service as a Percentage } \\
\text { of Exports of Goods and Services }\left(X_{15}\right)\end{array}$ & -2500.30 & 977.64 & -2.55 & $0.01^{* *}$ \\
\hline $\begin{array}{l}\text { Current Account as a Percentage of } \\
\text { Exports of Goods and Services }\left(X_{16}\right)\end{array}$ & 2134.60 & 1115.10 & 1.91 & $0.05^{\star *}$ \\
\hline $\begin{array}{l}\text { Net International Liquidity as Months of } \\
\text { Import Cover }\left(\mathrm{X}_{17}\right)\end{array}$ & 4362.13 & 1616.35 & 2.69 & $0.00^{* * *}$ \\
\hline Annual inflation rate $\left(\mathrm{X}_{18}\right)$ & -2656.54 & 1146.16 & -2.31 & $0.02^{* *}$ \\
\hline GDP per capita $\left(\mathrm{X}_{19}\right)$ & 8514.14 & 2557.67 & 3.32 & $0.00^{* * *}$ \\
\hline $\begin{array}{l}\text { Budget balance as a percentage of GDP } \\
\left(\mathrm{X}_{21}\right)\end{array}$ & 2149.47 & 1131.63 & 1.89 & $0.05^{\star *}$ \\
\hline No. of observations & 225 & & & \\
\hline Log likelihood & -2206.13 & & & \\
\hline Durbin-Watson statistics & 1.20 & & & \\
\hline$F$ test & 31.97 & & & $0.00^{* * *}$ \\
\hline Adjusted $\mathrm{R}^{2}$ & 0.85 & & & \\
\hline $\mathrm{R}^{2}$ & 0.88 & & & \\
\hline
\end{tabular}

denotes the significance of the value at a $1 \%$ level * denotes the significance of the value at a $5 \%$ level *denotes the significance of the value at a $10 \%$ level 


\section{CONCLUSION}

The main aim of this study was to explore in detail the role of political risks and institutions in host countries as determinants of foreign direct investment for fifteen major emerging market economies for the period 2000 to 2014 following a static panel data approach. This study examined the roles of macroeconomic uncertainty, political risk, as well as financial risk, and economic risk affecting FDI inflows in emerging economies. When international institutional investors such as multinational corporations (MNC) decide for direct investment in emerging countries, they take into account various risk perceptions such as political risk, financial risk and economic risk components apart from macroeconomic fundamentals. In the study, the literature that investigates the relationship between political risk and foreign direct investment was presented initially. After that, the study data covering the years between 2000 and 2014 and fifteen different countries were put forward.

The regression results show that among the selected twelve risk indicators, only seven indicators of political risks namely Government stability, Socioeconomic Conditions, Corruption, Military in Politics, religious tension, Law and Order, ethnic tension were found to be statistically significant in explaining variations in country level FDI inflows over time.

The results also show that financial risk components which were statistically significant are foreign debt service as a percentage of exports of goods and services, current account as a percentage of exports of goods and services and net international liquidity as months of import cover. In case of economic risk, three subcomponents were statistically significant such as annual inflation rate, GDP per capita, budget balance as a percentage of GDP.

From the above findings, key political risk components play an extremely important role in attracting FDI inflows and economic development in emerging economies. Political, financial, and economic risk factors are important matters for FDI. 


\section{REFERENCES}

Ahmed, S., \& Zlate, A. (2014). Capital flows to emerging market economies: A brave new world?. Journal of International Money and Finance, 48, 221-248.

Alfaro, L. (2017). Gains from foreign direct investment: Macro and micro approaches. The World Bank Economic Review, 30, 2-15.

Ali, F. A., Fiess, N., \& MacDonald, R. (2010). Do institutions matter for foreign direct investment?. Open Economies Review, 21(2), 201-219.

Asiri, B. K., \& Hubail, R. A. (2014). An empirical analysis of country risk ratings. Journal of Business Studies Quarterly, 5(4), 52-67.

Blonigen, B. A. (2005). A review of the empirical literature on FDI determinants. Atlantic Economic Journal, 33(4), 383-403.

Busse, M., \& Hefeker, C. (2007). Political risk, institutions and foreign direct investment. European Journal of Political Economy, 23(2), 397-415.

Calvo, G. A., Leiderman, L., \& Reinhart, C. M. (1993). Capital inflows and real exchange rate appreciation in Latin America: The role of external factors. Staff Papers, 40(1), 108-151.

Collier, P., \& Pattillo, C. (2000). Investment and risk in Africa. In P. Collier \& C. Pattillo (Ed.), Investment and risk in Africa (pp. 3-30). London: Palgrave Macmillan.

Demirhan, E., \& Masca, M. (2008). Determinants of foreign direct investment flows to developing countries: A cross-sectional analysis. Prague Economic Papers, 4(4), 356-369.

Eichengreen, B., Gupta, P., \& Masetti, O. (2018). Are capital flows fickle? Increasingly? And does the answer still depend on type?. Asian Economic Papers, 17(1), 22-41. 
Erkekoglu, H., \& Kilicarslan, Z. (2016). Do political risks affect the foreign direct investment inflows to host countries?. Journal of Business Economics and Finance, 5(2), 218-232.

Erramilli, M. K., \& Rao, C. P. (1993). Service firms' international entrymode choice: A modified transaction-cost analysis approach. Journal of Marketing, 57(3), 19-38.

Gastanaga, V. M., Nugent, J. B., \& Pashamova, B. (1998). Host country reforms and FDI inflows: How much difference do they make? World Development, 26(7), 1299-1314.

Grosse, R., \& Trevino, L. J. (1996). Foreign direct investment in the United States: An analysis by country of origin. Journal of International Business Studies, 27(1), 139-155.

Hayakawa, K., Kimura, F., \& Lee, H. H. (2013). How does country risk matter for foreign direct investment?. The Developing Economies, 51(1), 60-78.

Helpman, E., Melitz, M. J., \& Yeaple, S. R. (2004). Export versus FDI with heterogeneous firms. American Economic Review, 94(1), 300-316.

International Monetary Fund Report (2003).

Jude, C., \& Levieuge, G. (2017). Growth effect of foreign direct investment in developing economies: The role of institutional quality. The World Economy, 40(4), 715- 742.

Jyun-Yi, W., \& Chih-Chiang, H. (2008). Does foreign direct investment promote economic growth? Evidence from a threshold regression analysis. Economics Bulletin, 15(12), 1-10.

Kolstad, I., \& Tondel, L. (2002). Social development and foreign direct investments in developing countries (Research report R 2002: 11). Retrieved from https://open.cmi.no/cmi-xmlui/bitstream/handle/1125 0/2435857/Report $\% 20 \mathrm{R} \% 202002-11$.pdf? sequence $=2 \&$ isAllowed $=\mathrm{y}$ 
Kolstad, I., \& Villanger, E. (2008). Determinants of foreign direct investment in services. European Journal of Political Economy, 24(2), 518-533.

Krifa-Schneider, H., \& Matei, I. (2010). Business climate, political risk and FDI in developing countries: Evidence from panel data. International Journal of Economics and Finance, 2(5), 54-65.

Mukhopadhaya, D., \& Das, D. (2019). Impact of risk perceptions on foreign direct investment (FDI) inflows: A study of emerging economies. In R. Bhattacharyya (Ed.), The gains and pains of financial integration and trade liberalization (pp. 127-139). Emerald Publishing Limited.

Noorbakhsh, F., Paloni, A., \& Youssef, A. (2001). Human capital and FDI inflows to developing countries: New empirical evidence. World Development, 29(9), 1593-1610.

Palacios, A., \& Griffin, T. (2011). Country risks and FDI: Empirical evidence from Latin American countries. Journal of International Business Research, 10(1), 9-25.

PRS Group. (2017). International Country Risk Guide: Political Risk. Retrieved from http://www.icrgonline.com/default.aspx.

Tallman, S. B. (1988). Home country political risk and foreign direct investment in the United States. Journal of International Business Studies, 19(2), 219-233.

Thomas, J., \& Worrall, T. (1994). Foreign direct investment and the risk of expropriation. The Review of Economic Studies, 61(1), 81-108.

UNCTAD. (2015). International Investment Agreements. Geneva: United Nations.

UNCTAD (United Nations Conference on Trade and Development), World Investment Report 2013, United Nations press, Geneva and New York, 2014, pp. 2-8.

Valentine, M. (2015). The impact of party orientation and political risk and foreign direct investment inflows (Thesis, New York University). 
Retrieved from https://as.nyu.edu/content/dam/nyu-as/politics/docum ents/FINAL_Thesis_Marina_Valentini.pdf

Veld, C., \& Veld-Merkoulova, Y. V. (2008). An empirical analysis of the stockholder-bondholder conflict in corporate spin-offs. Financial Management, 37(1), 103-124.

Wei, S. (2000). Local corruption and global capital flows. Brooking Papers on Economic Activity, 31(2), 303-354.

Wheeler, D., \& Mody, A. (1992). International investment location decisions: The case of US firms. Journal of International Economics, 33(1-2), 57-76.

World Bank (2017). World Development Indicators. Retrieved from https:// www.worldbank.org/.

www.prsgroup.com.

www.unctad.org. 